\title{
Small Bore Thoracic Catheter Versus Chest Tube in Treatment of Primary Spontaneous Pneumothorax
}

\author{
- Murat Ersin Çardak, ${ }^{1}$ ( Kadir Burak Özer, ${ }^{2}$ () Ekin Ezgi Cesur, ${ }^{2}$ \\ (1) Attila Özdemir, ${ }^{2}$ ㄴ) Riza Serdar Evman, ${ }^{3}$ (ㄱ) Recep Demirhan ${ }^{2}$
}

\begin{abstract}
'Department of Thoracic Surgery,
Kartal Koşuyolu High Speciality

Training and Research Hospital, istanbul, Turkey

2Department of Thoracic Surgery, Kartal Dr. Lütfi Kırdar Training and Research Hospital, ístanbul, Turkey

${ }^{3}$ Department of Thoracic Surgery, İstanbul Süreyyapaşa Chest Diseases and Thoracic Surgery Training and Research Hospital, Istanbul, Turkey
\end{abstract}

Submitted: 06.05.2019 Accepted: 22.07.2019

Correspondence: Murat Ersin Çardak, Istanbul Kartal Koşuyolu Yüksek Ihtisas Eğitim ve Araştırma Hastanesi, Göğüs Cerrahisi Kliniği, Istanbul, Turkey

E-mail: ersincardak@gmail.com

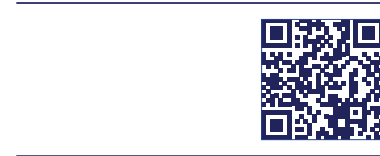

Keywords: Chest tube; primary spontaneous pneumothorax; small bore thoracic catheters.

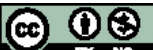

This work is licensed under a Creative Commons Attribution-

\begin{abstract}
Objective: The primary treatment of primary spontaneous pneumothorax (PSP) is still controversial. The large-bore thoracic catheter has traditionally been used, but there is now a global trend toward the increased use of the small-bore thoracic catheters (SBTC). The present study aims to compare the use of SBTC and chest tube (CT) in first-line treatment of PSP.
\end{abstract}

Methods: This prospective randomized study included 90 patients diagnosed with PSP. The patients were randomly distributed into two groups. In the first group, catheter thoracostomy was applied with an 8 French thorax catheter and in the other group, a tube thoracostomy with a 28 French chest tube. The parameters used for comparison in this study were defined as pneumothorax side, pneumothorax size, pain, need of additional analgesia, malpositioning drain, duration of air leakage, duration of hospitalization, complications and recurrence.

Results: In the evaluation of pain using the Numerical Rating Scale (NRS) at I, 4, 12 and 24 hours after the application, the mean NRS values of the SBTC patients were seen to be lower than those of the CT patients but at I, 12 and 24 hours, the difference was not statistically significant. At the $4^{\text {th }}$ hour, the difference was determined to be statistically significant $(p=0.022)$. The duration of air leakage was $1.7 \pm 1.4$ days for the SBTC group and $2.2 \pm 1.9$ days for the CT group. The period of termination of the drain was $3.3 \pm 1.2$ days for the SBTC group and $4.0 \pm 1.7$ days for the CT group. The duration of hospitalization was $3.5 \pm 1.3$ days for the SBTC group and $4.5 \pm 1.9$ days for the CT group.

Conclusion: No significant difference was determined in respect of air leakage, hospital stay, failure rates or complications between the two procedures. When compared concerning postoperative pain, ease of application, patient comfort and incision scar, SBTC can be considered to be subjectively superior to $\mathrm{CT}$, and can be used safely in the treatment of PSP.

\section{INTRODUCTION}

Primary spontaneous pneumothorax (PSP) is defined as a pneumothorax occurring spontaneously in a patient without any underlying lung disease. PSP most commonly arises in young, tall, lean males. The age-adjusted incidence is 7.4 to 18 per 100000 populations per year in males and 1.2 to 6 per 100000 populations per year in females. ${ }^{[]]}$There is no consensus concerning the primary treatment of PSP, although underwater-seal chest tube drainage is the most popular and recommended air evacuation technique. The large-bore thoracic catheter has traditionally been used for drainage of the thoracic cavities, but there is now a global trend toward the increased use of small-bore thoracic catheters. ${ }^{[2]}$

The present study aims to compare the use of a small-bore thoracic catheter (SBTC) and chest tube (CT) in first-line treatment of PSP concerning effectiveness, clinical outcomes and complications.

\section{MATERIALS AND METHODS}

\section{Patient selection}

Written informed consent was obtained from each patient. The study protocol was approved by the local Ethics Committee. 
This prospective randomized study included 90 patients diagnosed with PSP in our clinic. Patients with no clinical or radiological findings of pulmonary disease were accepted as PSP cases. Any patients with secondary spontaneous pneumothorax or recurrence were excluded from this study.

Of the total 90 patients diagnosed with PSP, SBTC was applied to 45 and CT to 45 . The patients comprised 42 male $(93.4 \%)$ and three female $(6.6 \%)$ patients in the CT group and of 45 (100\%) male patients in the SBTC group. The mean age of the patients was $27.6 \pm 9.7$ years, with a peak determined at 20-25 years. From the anamnesis, cigarette smoking was determined in $54(60 \%)$ patients, 30 in the SBTC group and 24 in the CT group. The mean BMI of the total patient group was determined as $21.5 \pm 2.9$. Complaints on admission were chest pain accompany dyspnea in $69(76.6 \%)$ patients, dyspnea in $15(16.6 \%)$ and severe chest pain in six $(6.6 \%)$ patients.

According to the order of admission to the clinic, the patients were distributed into two groups using block randomization techniques. Block size of 4 was chosen, and in group $A$, catheter thoracostomy was applied with an 8 French $(F)$ thorax catheter and in the other group (Group $\mathrm{B})$, a tube thoracostomy with a $28 \mathrm{~F}$ chest tube. It was planned to evaluate each group and to compare the results.

\section{Surgical technique}

In 45 patients, a small-bore thoracic catheter was used and in 45 patients, a $28 \mathrm{~F}$ chest tube. Both thoracostomy procedures were applied with the patient in a semi-Fowler's position under local anesthetic (prilocaine $\mathrm{HCl}$ ) from the 5 th intercostal space on the mid-axillary line.

In the application of the SBTC, skin incision of approximately $3 \mathrm{~mm}$ was made and the cannula of the catheter was entered in the thorax under local anesthesia. After passing the pleura, using the cannula as a guide, it was placed in the thorax. The catheter was fixed with $2 / 0$ silk suture and connected to underwater seal drainage.

The application of CT was also made under local anesthesia. Following a skin incision of approximately $1.5 \mathrm{~cm}$, subcutaneous and fatty tissue, the muscles and the pleura were dissected using a Kelly clamp, and the drain was placed in the thorax. It was fixed with a U-suture of No. 0 silk and underwater seal drainage was applied.

To verify the positions of the catheters and drains, a PA chest $\mathrm{x}$-ray was taken for all the patients after the procedures. Malpositioning of the catheter or drains was defined as those not oriented towards the apex, but horizontal or towards the diaphragm. Before the applications, prophylaxis of I gr cefazolin sodium was administered. After the application, all patients were routinely administered $8 \mathrm{mg}$ lornoxicam $\times 2 /$ day, $500 \mathrm{mg}$ paracetamol x 4/day and 40 $\mathrm{mg}$ pantoprazole $\times \mathrm{I} /$ day until the day that the drain was terminated. At I, 4, 12 and 24 hours after the application, the Numerical Rating Scale (NRS) was applied with the patients scoring pain from 0-10. Twenty-four hours after full expansion of the lung and air leakage was stopped, the drain was terminated. Follow-up $x$-rays were taken on the $10^{\text {th }}$ day, then on $1^{\text {st }}, 6^{\text {th }}$ and $12^{\text {th }}$ months.

\section{Data collection and statistical analysis}

Following the medical history and physical examination, a routine PA chest $x$-ray was taken. To make the intervention for pneumothorax, the base criteria taken were the patient complaints, the clinical status and expansion defect of more than $20 \%$ according to the Light Index (\% pneumothorax $=100 \times[\mathrm{I}-$ (lung diameter/hemithorax diameter)3]) on the PA pulmonary radiograph. ${ }^{[3]}$

The parameters used for comparison in this study were defined as pneumothorax side, pneumothorax size (according to Light Index), and pain after the intervention, the need for additional analgesia, drain malpositioning, duration of air leakage, duration of hospitalization, complications and recurrence.

The statistical package of social sciences (SPSS) software (ver. 17.0 for Windows) was used for all statistical analyses. Numerical variables were stated as mean \pm standard deviation (SD) or median (minimum- maximum). Categorical variables were stated as numbers and percentages. In the group comparisons, the Mann-Whitney U-test was used and in independent groups, the t-test, Friedman test, Chi-square test and Spearman correlation measurement. Maximum type I error was accepted as 0.05 and a value of $\mathrm{p}<0.05$ was accepted as statistically significant.

\section{RESULTS}

Pneumothorax was on the right side in 5 I (56.6\%) patients and on the left side in $39(43.3 \%)$ patients. According to the Light Index criteria, the mean size of the pneumothorax was calculated as $57.5 \% \pm 22.7 \%(21 \%-93 \%)$. The size of the pneumothorax, according to the application, was calculated as $49.7 \% \pm 24.2 \%$ in the SBTC patients and $65.4 \% \pm 18.6 \%$ in the $\mathrm{CT}$ patients. According to the clinical presentation and demographics, groups were found to be homogeneous (Table I).

Malpositioning was seen in two (4.4\%) patients in the SBTC group and $5(26.6 \%)$ in the CT group. The difference between the groups was not statistically significant

Table I. Clinical characteristics of PSP patients treated with the SBTC and the CT

\begin{tabular}{lccc}
\hline & SBTC $(\mathbf{n = 4 5 )}$ & CT $(\mathbf{n}=45)$ & p \\
\hline Age (years) & $24.2 \pm 7.1$ & $30.9 \pm 11.0$ & 0.059 \\
Major symptoms & & & \\
$\quad$ Chest pain & 3 & 3 & 0.885 \\
$\quad$ Dyspnea & 6 & 9 & \\
$\quad$ Pain + Dyspnea & 36 & 33 & \\
Size of PTX (\%) & $49.7 \pm 24.2$ & $65.4 \pm 18.6$ & 0.056
\end{tabular}

CT: Chest tube; PTX: Pneumothorax; SBTC: Small-bore thoracic catheter. 
$(p=0.32)$. There was no need for repositioning of the drain or catheter in any patient since the lungs were all fully expanded in chest $\mathbf{x}$-rays.

In the evaluation of pain using the NRS at I, 4, 12 and 24 hours after the application, the mean NRS values of the SBTC patients were seen to be lower than those of the CT patients but at I, 12 and 24 hours, the difference was not statistically significant $(p=0.274,0.094$ and 0.082 , respectively). At the $4^{\text {th }}$ hour, the difference was determined to be statistically significant $(p=0.022)$. There was a significant reduction from the $I^{\text {st }}$ to the $24^{\text {th }}$ hour in both application groups ( $p=0.004$ and 0.013 , respectively). There was no requirement for additional analgesia in any patient (Table 2).

The duration of air leakage was $1.9 \pm 1.7$ days in the whole study group: $1.7 \pm 1.4$ days for the SBTC group and $2.2 \pm 1.9$ days for the CT group. The time for termination of the drain was $3.7 \pm 1.5$ days for the whole group: $3.3 \pm 1.2$ days for the SBTC group and $4.0 \pm 1.7$ days for the CT group. The duration of hospitalization was determined as $4.0 \pm 1.7$ days for the whole group: $3.5 \pm 1.3$ days for the SBTC group and $4.5 \pm 1.9$ days for the CT group. Despite these slight differences in favor of the SBTC group, the divergence did not reach the significance level (Table 3).

Table 2. Comparison of NSR in PSP patients treated with the SBTC and the CT

\begin{tabular}{|c|c|c|c|c|}
\hline Groups & & $\mathbf{N}$ & Mean & $\mathbf{p}$ \\
\hline \multirow[t]{2}{*}{ NSR I ${ }^{\text {st }}$ hour } & SBTC & 45 & 3.73 & 0.274 \\
\hline & CT & 45 & 4.60 & \\
\hline \multirow[t]{2}{*}{ NSR $4^{\text {th }}$ hour } & SBTC & 45 & 3.00 & 0.022 \\
\hline & CT & 45 & 4.73 & \\
\hline \multirow[t]{2}{*}{ NSR $12^{\text {th }}$ hour } & SBTC & 45 & 2.40 & $0.094^{*}$ \\
\hline & CT & 45 & 3.93 & \\
\hline \multirow[t]{2}{*}{ NSR $24^{\text {th }}$ hour } & SBTC & 45 & 2.20 & $0.082^{*}$ \\
\hline & $\mathrm{CT}$ & 45 & 3.47 & \\
\hline
\end{tabular}

"Student t-test; "Mann-Whitney U test. NRS: Numerical rating scale; CT: Chest tube; SBTC: Small-bore thoracic catheter; PSP: primary spontaneous pneumothorax.

Table 3. Comparison of air leakage, drain termination and hospital stay in PSP patients treated with the SBTC and the CT

\begin{tabular}{llccc}
\hline & & N & $\begin{array}{c}\text { Mean } \\
\text { (days) }\end{array}$ & p* \\
\hline Air leakage & SBTC & 45 & 1.70 & 0.414 \\
& CT & 45 & 2.20 & \\
Drain termination & SBTC & 45 & 3.33 & 0.235 \\
& CT & 45 & 4.07 & \\
Hospital stay & SBTC & 45 & 3.53 & 0.173 \\
& CT & 45 & 4.53 & \\
\hline
\end{tabular}

"2-tailed values; Mann-Whitney $U$ test was used. CT: Chest tube; SBTC: Small-bore thoracic catheter; PSP: Primary spontaneous pneumothorax.
No additional treatment was applied after air drainage. In groups, no air leakage and/or expansion defect longer than seven days was detected. No mortality or major complications (hemorrhage, empyema/infection, lung laceration, re-expansion edema) were seen in either group during the application or follow-up period. At the end of the oneyear follow-up, a hypertrophic scar was observed in the application site of all the patients in the CT group.

\section{DISCUSSION}

The primary treatment choice for PSP is still controversial. In the British Thoracic Society (BTS) guidelines, the first-line treatment in PSP is recommended as simple aspiration, and success rates have been reported to be similar to those of CT. ${ }^{[4]}$ Other national or consensus guidelines recommend either needle aspiration or smallbore chest catheter placement. ${ }^{[5]}$ However, in 200I, the American College of Chest Physicians (ACCP) reported that the first treatment choice for patients with PSP should be chest drain with underwater-seal or Heimlich valve. ${ }^{[6]}$ Previous studies have shown that tube thoracostomy has been more widespread in practice..$^{[7]}$ In a study by Mendis et al.," ${ }^{[8]}$ tube thoracostomy was found to be the first choice of surgeons at the rate of $27 \%$, despite their national guidelines accepted simple aspiration as the primary treatment choice.

Although there is no accepted guideline in our country, Turkey, for the treatment of pneumothorax, tube thoracostomy has been recommended as the primary treatment in previous studies. ${ }^{[9,10]}$ The ACCP recommends the application of a standard 16-22F chest drain or a smallbore catheter $(\leq 14 \mathrm{~F})$ and the BTS in the Pleural Procedures Guide recommends the placement of a small-bore chest catheter for pneumothorax. ${ }^{\left[{ }^{\prime \prime}\right]}$ In literature, it has been reported that, generally, a small-bore chest catheter is sufficient in pneumothorax treatment. ${ }^{[12-15]}$ Despite many studies in literature and treatment guides, a survey study in the Czech Republic reported that $75 \%$ of the chest surgeons would apply tube thoracostomy to patients with PSP, and $85 \%$ of those would prefer to use a 20-24F drain. ${ }^{[16]}$ In another study in Sweden, the general preference was reported to be a $16-22 \mathrm{~F}$ chest drain. ${ }^{[17]}$ These studies show that the preference of chest surgeons is a large bore drain. As there is limited information available on the efficacy and morbidity of small-bore chest drains, chest surgeons tend to prefer the application of traditional methods. ${ }^{[18]}$

Drainage made with a chest drain has associated complications, such as pain, pleural infection, malpositioning, hemorrhage, hypotension, ${ }^{[19]}$ and pulmonary edema, due to pulmonary re-expansion. ${ }^{[20]}$ Recurrent pneumothorax, which occurs following termination of the chest drain, is a significant complication. In a study by Palesty, it was reported that after drain removal, recurrent pneumothorax developed in $10.9 \%$ of cases and the drain was re-applied to $2 \%$ of patients. ${ }^{[21]}$ In the present study, when CT was being 
terminated, the drain was removed at the end of forced inspiration, but no special maneuver was made when terminating SBTC. In addition, it was observed that for the patients, termination of $\mathrm{CT}$ was stressful and painful, but these subjective complaints were not reported by the patients during the termination of SBTC. No complications or failures were observed in either group. A statistically significant decrease was seen in the NRS from the I ${ }^{\text {st }}$ hour to the $24^{\text {th }}$ hour. At the $4^{\text {th }}$ hour, as there was a statistically significant difference between the two groups in respect to the NRS values, this showed that the SBTC was a less painful procedure in the early stage. Other advantages of SBTC as a technique are that it is more comfortable than $C T$ and the application is easier. The relatively reduced malpositioning in SBTC is thought to be due to the use of the catheter cannula as a guide. As the incision for SBTC is smaller and fixation is made with finer sutures, rapid wound healing and in the long-term and less scar tissue formation is achieved.

The majority of recurrent cases of spontaneous pneumothorax occur within the first six months. ${ }^{[22]}$ In the current study, recurrence developed within the first month in two patients in the CT group. No recurrence was seen in the SBTC group during the 12-month follow-up period. No statistically significant difference was determined between the two groups in respect to recurrence.

In a prospective study by Delius et al. ${ }^{[23]}$ of 36 patients with spontaneous pneumothorax (primary and secondary pneumothorax together), the success rate of the small-bore catheter was reported as $53 \%$. In a retrospective study by Aplin, the small-bore catheter was applied to 1 I7 patients with spontaneous pneumothorax and a success rate of $72 \%$ was reported. ${ }^{[24]}$ In a study by Liu et al., ${ }^{[25]}$ a retrospective comparison was made of chest drain $(n=52)$ and small-bore catheter $(n=50)$, and no significant difference was attained between the two groups in respect of the duration of hospital stay. In the same study, the success rate of the small-bore catheter was found to be $70 \%$.

Our study revealed no significant difference between $8 \mathrm{~F}$ chest catheter and $28 \mathrm{~F}$ chest drain in terms of duration of air leakage, drain use, or hospital stay. In this study, the main limitation was the long term follow up of the patients. The recurrence rates on the long term follow up will show more accurate findings. In conclusion, no significant difference was determined in respect to air leakage, hospital stay, failure rates or complications between the two procedures. When compared concerning postoperative pain, ease of application, patient comfort and incision scar, SBTC can be considered to be subjectively superior to $C T$ and can be used safely in the treatment of primary spontaneous pneumothorax. However, for more definitive evidence, there is a need for further more comprehensive studies with larger patient cohorts.

Informed Consent

Prospective study.
Peer-review

Internally peer-reviewed.

Authorship Contributions

Concept: M.E.Ç.; Design: K.B.Ö.; Supervision: R.D.; Fundings: R.D.; Materials: A.Ö.; Data: K.B.Ö.; Analysis: K.B.Ö.; Literature search: E.E.C., R.S.E.; Writing: K.B.Ö., M.E.Ç.; Critical revision: E.E.C.

Conflict of Interest

None declared.

\section{REFERENCES}

1. Melton LJ 3rd, Hepper NG, Offord KP. Incidence of spontaneous pneumothorax in Olmsted County, Minnesota: 1950 to 1974. Am Rev Respir Dis 1979;120:1379-82.

2. Cho S, Lee EB. Management of primary and secondary pneumothorax using a small-bore thoracic catheter. Interact Cardiovasc Thorac Surg 2010;11:146-9. [CrossRef]

3. Light RW. Pneumothorax. In: Pleural diseases. Baltimore: Williams \& Wilkins; 2007.p. 306-39.

4. MacDuff A, Arnold A, Harvey J. Management of spontaneous pneumothorax: British Thoracic Society Pleural Disease Guideline 2010. Thorax 2010;65:18-31. [CrossRef]

5. De Leyn P, Lismonde M, Ninane V, Noppen M, Slabbynck H, Van Meerhaeghe A, et al. Guidelines Belgian Society of Pneumology. Guidelines on the management of spontaneous pneumothorax. Acta Chir Belg 2005;105:265-7. [CrossRef]

6. Baumann MH, Strange C. The clinician's perspective on pneumothorax management. Chest 1997;112:822-8. [CrossRef]

7. Ong ME, Chan YH, Kee TY, Chew HC, Koh MS. Spontaneous pneumothorax outcome study (Spot phase I): A 2-year review. Eur J Emerg Med 2004;11:89-94. [CrossRef]

8. Mendis D, El-Shanawany T, Mathur A, Redington AE. Management of spontaneous pneumothorax: are British Thoracic Society guidelines being followed? Postgrad Med J 2002;78:80-4. [CrossRef]

9. Türkyılmaz A, Erdem AF, Aydın Y, Çinici Ö, Eroğlu A. Sekonder Spontan Pnömotoraksta Tedavi: 100 Olguluk Tecrübe. [Article in Turkish]. Eurasian J Med 2007;39:97-102.

10. Demirhan R, Koşar A, Eryiğit H, Kıral H, Yıldırım M, Arman B. Spontaneous pneumothorax: retrospective analysis of 348 cases. [Article in Turkish]. Ulus Travma Acil Cerrahi Derg 2009;15:367-70.

11. Havelock T, Teoh R, Laws D, Gleeson F; BTS Pleural Disease Guideline Group. Pleural procedures and thoracic ultrasound: British Thoracic Society Pleural Disease Guideline 2010. Thorax 2010;65:ii61-76. [CrossRef]

12. Conces DJ Jr, Tarver RD, Gray WC, Pearcy EA. Treatment of pneumothoraces utilizing small caliber chest tubes. Chest 1988;94:55-7.

13. Minami H, Saka H, Senda K, Horio Y, Iwahara T, Nomura F, et al. Small caliber catheter drainage for spontaneous pneumothorax. Am J Med Sci 1992;304:345-7. [CrossRef]

14. Martin T, Fontana G, Olak J, Ferguson M. Use of pleural catheter for the management of simple pneumothorax. Chest 1996;110:1169-72.

15. Vedam H, Barnes DJ. Comparison of large and small-bore intercostal catheters in the management of spontaneous pneumothorax. Int Med J 2003;33:495-9. [CrossRef]

16. Stolz A, Harustiak T, Pafko. P Spontaneous pneumothorax management. Eur Surg 2008;40:187-92. [CrossRef]

17. Kuester JR, Frese S, Stein RM, Roth T, Beshay M, Schmid RA. Treatment of primary spontaneous pneumothorax in Switzerland: results of a survey. Interact Cardiovasc Thorac Surg 2006;5:139-44. 
18. Cafarotti S, Dall'Armi V, Cusumano G, Margaritora S, Meacci E, Lococo F, et al. Small-bore wire-guided chest drains: safety, tolerability, and effectiveness in pneumothorax, malignant effusions, and pleural empyema. J Thorac Cardiovasc Surg 2011;141:683-7. [CrossRef]

19. Pavlin DJ, Raghu G, Rogers TR, Cheney FW. Reexpansion hypotension. A complication of rapid evacuation of prolonged pneumothorax. Chest 1986;89:70-4. [CrossRef]

20. Rozenman J, Yellin A, Simansky DA, Shiner RJ. Re-expansion pulmonary oedema following spontaneous pneumothorax. Respir Med 1996;90:235-8. [CrossRef]

21. Palesty JA, McKelvey AA, Dudrick SJ. The efficacy of X-rays after chest tube removal. Am J Surg 2000;179:13-6. [CrossRef]

22. Baumann MH. Management of spontaneous pneumothorax. Clin Chest Med 2006;27:369-81. [CrossRef]

23. Delius RE, Obeid FN, Horst HM, Sorensen VJ, Fath JJ, Bivins BA. Catheter aspiration for simple pneumothorax. Experience with 114 patients. Arch Surg 1989;124:833-6. [CrossRef]

24. Aplin P. Size does make a difference in management of spontaneous pneumothoraces. Emerg Med 1996;8:221-5. [CrossRef]

25. Liu CM, Hang LW, Chen WK, Hsia TC, Hsu WH. Pigtail tube drainage in the treatment of spontaneous pneumothorax. Am J Emerg Med 2003;21:241-4. [CrossRef]

\section{Primer Spontan Pnömotoraks Tedavisinde Küçük Çaplı Toraks Katateri Ile Toraks Dreni Uygulamasının Karşılaştııılması}

Amaç: Primer spontan pnömotoraks primer tedavisi halen tartışmalıdır. Standart tedavi yaklaşımında geniş çaplı taraks drenleri kullanılmakla birlikte günümüzde global küçük çaplı toraks kateteri uygulaması yaygınlaşmaktadır. Çalışmamızda, primer spontan pnömotoraks ilk basamak tedavisinde küçük çaplı toraks kateteri (KÇTK) ile toraks dreni (TD) uygulamasının karşılaştırılması amaçlanmaktadır.

Gereç ve Yöntem: Primer spontan pnömotoraks tanılı 90 olgu ileriye yönelik ve randomize olarak değerlendirmeye alındı. Olgular randomize olarak iki gruba ayrıldı. Bir gruba 8 french toraks kateteri, diğer gruba ise 28 french toraks dreni uygulandı. Her iki grup değerlendirilerek sonuçları kaydedildi. Değerlendirme kriterleri, pnömotoraks tarafı, pnömotoraks miktarı, ağıı, ek analjezi ihtiyacı, kateter ve dren malpozisyonu, hava kaçağı süresi, hastanede yatış süresi, komplikasyonları ve nüks idi.

Bulgular: Ağrı için işlemi takiben I., 4., I2. ve 24. saatlerde sayısal değerlendirme ölçeği (SDÖ) kullanılarak kaydedildi. Olguların I., I2. ve 24. saatlerde kaydedilen ortalama SDÖ değerleri küçük çaplı toraks kateteri uygulananlarda daha düşük olarak izlendi fakat istatistiksel olarak anlamlı bulunmadı ( $p=0.274,0.094$ ve 0.082 ). Fakat dördüncü saatte yapılan ölçümde istatistiksel olarak anlamlı değerler kaydedildi $(0.022)$.

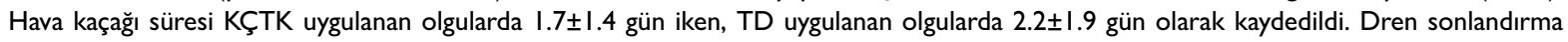
süresi KÇTK grubunda $3.3 \pm 1.2$ gün ve TD grubunda $4.0 \pm 1.7$ gün saptandı. Hastanede yatış süreleri ise KÇTK grubunda $3.5 \pm 1.3$ gün iken, TD grubunda $4.5 \pm 1.9$ idi.

Sonuç: Her iki prosedürün karşılaşıtırılmasında, hava kaçağı süresi, hastanede yatış süresi, işlem başarısızlık oranları ve komplikasyonlar açısından istatistiksel anlamlı farklılık izlenmedi. İ̧̧lem sonrası ağrı, işlemin uygulama kolaylığı, hasta konforu, insizyon skarı gibi özellikleri açısından KÇTK subjektif olarak daha avantajlı ve primer spontan pnömotoraks tedavisinde güvenle kullanılabilen bir yöntem olarak değerlendirildi.

Anahtar Sözcükler: Primer spontan pnömotoraks; toraks dreni; toraks katateri. 